\title{
PENGEMBANGAN PERANGKAT PEMBELAJARAN MODEL INKUIRI TERBIMBING BERBANTUAN TEKNIK MIND MAPPING UNTUK MENINGKATKAN PENGUASAAN KONSEP DAN KEMAMPUAN BERPIKIR KREATIF SISWA SMP
}

\author{
Erna Suhartini ${ }^{1)}$, Z.A. Imam Supardi ${ }^{2)}$, Rudiana Agustini ${ }^{3)}$ \\ ${ }^{1)}$ Mahasiswa Program Studi Pendidikan Sains, Program Pascasarjana Universitas Negeri Surabaya \\ ${ }^{2), 3)}$ Dosen Pascasarjana Prodi Pendidikan Sains Univesrtitas Negeri Surabaya \\ E-mail: erna_vck3d@yahoo.co.id
}

\begin{abstract}
The purpose of this research is producing physics learning material through guided inquiry model with Mind Mapping technique that valid, practical, and effective to improve comprehension of concept and creative thinking ability of student in junior high school. The development of learning material used the Kemp model and was try outed in class VII of SMP Al Azhar Syifa Budi Samarinda, second semester in academic year 2013/2014 with One-Group Pretest-Posttest Design. The data collection used observation method, test, and quetionnaires. The data analysis techniques used quantitative descriptive analysis. The results of this research are: 1) Learning material developed has a valid category; 2) The practicality of learning material in terms of a good category in feasibility of lesson plans and the students' activities in accordance with steps of guided inquiry model with Mind Mapping technique; and 3) The learning material effectiveness in terms of: (a) Improving students comprehension of concept seen from the N-gain score with high category; (b) Improving creative thinking ability of student by getting the N-gain score with high category; and (c) The students' responds toward material and implementation of learning are very positive.

It's conclusion that the learning material through guided inquiry model with Mind Mapping technique are decent to improve comprehension of concept and creative thinking ability of student in junior high school.
\end{abstract}

\section{Keywords: Learning material, guided inquiry, Mind Mapping, Comprehension of Concept, Creative Thinking.}

\begin{abstract}
Abstrak: Penelitian ini bertujuan untuk menghasilkan perangkat pembelajaran fisika model inkuiri terbimbing berbantuan teknik mind mapping yang valid, praktis dan efektif (layak) untuk meningkatkan penguasaan konsep dan kemampuan berpikir kreatif siswa SMP. Pengembangan perangkat pembelajaran menggunakan model Kemp dan diujicobakan di kelas VII SMP Al Azhar Syifa Budi Samarinda semester genap tahun ajaran 2013/2014 dengan One-Group Pretest-Posttest Design. Pengumpulan data menggunakan metode observasi, tes, dan angket. Teknik analisis data menggunakan analisis deskriptif kuantitatif. Temuan hasil penelitian, yaitu: 1) Perangkat pembelajaran yang dikembangkan berkategori valid; 2) Kepraktisan perangkat pembelajaran ditinjau dari keterlaksanaan RPP berkategori baik dan aktivitas siswa sesuai dengan tahap-tahap pada model inkuiri terbimbing berbantuan teknik mind mapping; dan 3) Keefektifan perangkat pembelajaran ditinjau dari: (a) Peningkatan penguasaan konsep siswa yang terlihat dari $\mathrm{N}$-gain dengan kategori tinggi; (b) Peningkatan kemampuan berpikir kreatif siswa yang terlihat dari Ngain dengan kategori tinggi; dan (c) Respon siswa terhadap perangkat dan pelaksanaan pembelajaran sangat positif. Simpulan dari penelitian ini adalah perangkat pembelajaran model inkuiri terbimbing berbantuan teknik mind mapping yang dikembangkan layak untuk meningkatkan penguasaan konsep dan kemampuan berpikir kreatif siswa SMP.
\end{abstract}

Kata kunci: Perangkat pembelajaran, inkuiri terbimbing, Mind Mapping, Penguasaan Konsep, Berpikir Kreatif.

\section{PENDAHULUAN}

Evaluasi dan perubahan kurikulum dari KTSP 2006 menjadi KTSP 2013 menitik beratkan pada pentingnya penyiapan sumber daya manusia (SDM) yang punya soft skills dan hard skill. Kesadaran akan pentingnya soft skills tidak sejalan dengan pembentukanya yang begitu sulit, ironisnya justru Soft Skills sering diabaikan pada sistem sekolah konvensional. Menurut Stanberg (dalam Forum Mangunwijaya VII 2013) Hard skill bisa dipelajari dengan membaca buku, menghafal dan latihan berulang akan tetapi, mengajarkan siswa untuk cakap mengolah emosi, berkarakter baik, punya motivasi, kritis, kreatif perlu usaha besar dan teknik tersendiri.

Pelajaran IPA termasuk fisika juga membutuhkan soft skill dan hard skill hal itu tercermin dalam 4 unsur hakikat pembelajaran IPA yang meliputi sikap, proses, produk, dan aplikasi. Upaya pemenuhan ke-4 unsur hakikat IPA tersebut, kendala dan kesulitan serta hasil yang kurang maksimal sering dijumpai di kelas. Proses 
pembelajaran yang masih berpusat pada guru teachercentered yang membuat siswa menjadi pasif diduga menjadi salah satu penyebabnya dan sebagai hasil akhirnya dapat dilihat pada rendahnya hasil belajar siswa pada pelajaran IPA khususnya fisika. Siswa sudah terbiasa menjawab pertanyaan dengan prosedur rutin. Hal ini terlihat jelas dari hasil TIMMS 2011 (Trends in International Math and Science Survey), yang menempatkan siswa Indonesia dalam bidang sains di urutan ke 40 dengan skor 406 dari 42 negara, pada kategori kemampuan berpikir advance yaitu mengolah informasi, membuat generalisasi menyelesaiakan masalah non rutin, serta mengambil kesimpulan (Pusat Penilaian Pendidikan Balitbang Kemdikbud, 2011).

Hasil TIMMS tersebut juga tidak luput dari faktor lemahnya kemampuan siswa untuk terampil secara intelektual. Salah satu keterampilan intelektual yang dimaksudkan adalah keterampilan mengembangkan daya cipta atau pemikiran kreatif agar ia menjadi individu yang kreatif (Gie TL, 2003:42). Begitu pentingnya berpikir kreatif dalam kegiatan pembelajaran, Spittler menjelaskan bahwa berpikir kreatif dapat mempersiapkan siswa berpikir dalam berbagai disiplin ilmu, menuju pemenuhan akan kebutuhan intelektualnya dan mengembangkanya sebagai individu berpotensi.

Pengembangan berpikir kreatif pada praktik pendidikan dan pembelajaran kita, kurang dijadikan tujuan pembelajaran. Pembelajaran di sekolah-sekolah telah dikebiri menjadi perolehan informasi dengan sistem tagihan yang mengutamakan hasil belajar jangka pendek dan hanya dipandang dalam satu dimensi yaitu dimensi produk saja, sementara pembentukan kemampuan-kemampuan yang memerlukan jangka waktu lebih lama serta merupakan misi lintas mata pelajaran, seperti kemampuan berpikir, kemampuan menyelesaikan masalah, dan memandang pengalaman belajar sebagai suatu sistem pola berpikir yang logis dan kreatif, masih cukup jauh tertinggal penangananya.

Pemerintah dalam meninjau tantangan di atas, dalam Permendikbud No. 58 Tahun 2014 tentang Standar Proses Pendidikan Dasar dan Menengah telah mengisyaratkan tentang perlunya proses pembelajaran yang dipandu dengan kaidah-kaidah pendekatan saintifik/ilmiah. Penerapan pendekatan Saintifik memungkinkan siswa dibelajarkan dan dibiasakan untuk menemukan kebenaran ilmiah, bukan diajak untuk beropini dalam melihat suatu fenomena. Mereka dilatih untuk mampu berfikir logis, runut dan sistematis, dengan menggunakan kapasistas berfikir tingkat tinggi (High Order Thingking/HOT).

Model pembelajaran yang mendukung kaidahkaidah pendekatan saintifik adalah Inkuiri. Model pembelajaran inkuiri memungkinkan siswa untuk secara aktif maksimal menemukan sendiri konsep atau pengetahuan baru melalui proses hands-on and mind-on activity. Siswa yang belum terbiasa menggunakan model Inkuiri, maka sebagai pengawal dapat digunakan Guided Inquiry (Inkuiri Terbimbing).

Kuhlthau dkk (2006:6) mengatakan bahwa guided inquiry (penyelidikan terbimbing) bahwa ide atau gagasan yang diperoleh siswa bertahan lama karena siswa terlibat secara aktif bekerjasama dengan guru dan siswa lainnya dalam proses pembelajaran dari tahap perencanaan sampai akhirnya terbentuk ide tersebut, bahkan dikaitkan langsung dengan kehidupan siswa. Disimpulkan bahwa pembelajaran dengan menggunakan pendekatan inkuiri terbimbing lebih menekankan kepada memanipulasi objek dan lain-lain percobaan, sebelum sampai pada generalisasi yang mana siswa aktif terlibat di dalamnya. Artinya siswa sendiri atau kelompok secara aktif mencari informasi baru berdasarkan informasi yang diketahui sebelumnya dengan bimbingan guru. Siswa dalam pembelajaran ini tidak lagi menjadi penerima pasif, siswa lebih aktif terlibat dalam menyelidiki, menginvestigasi, mencoba dan akhirnya menemukan sendiri konsep IPA yang dimaksud.

Berdasarkan karakteristik inkuiri terbimbing yang telah dikemukakan maka tentunya akan lebih mudah bila dalam proses penemuanya, juga didukung oleh cara belajar (How-to learn?) yang efektif. Mengetahui cara belajar yang efektif adalah sebuah keharusan agar konsep atau pengetahuan baru yang dipelajari dapat dengan mudah diserap oleh otak dan dapat dipanggil kembali jika siswa membutuhkanya (Windura: 2013).

Sebuah sistem yang menawarkan kepada kita untuk dapat memaksimalkan cara belajar peserta didik adalah dengan penggunaan teknik Mind Map. Ditemukan oleh pakar memori dari Inggris pada tahun 1970 Tony Buzan menemukan teknik pencatatan yang didasarkan pada riset bagaimana cara kerja otak sebenarnya. Otak ternyata mengolah informasi dan menyimpan informasi tidak secara linear, setahap-demi setahap, tetapi otak menyimpan informasi dan memproses informasi secara acak dan otak menyimpan informasi dalam bentuk gambar, simbol, suara, dan bukan dalam bentuk huruf dan tulisan. Buzan (2006) menerangkan bahwa teknik Mind Mapping dapat memaksimalkan kerja otak kanan dan otak kiri sehingga yang tercipta adalah "sinergi otak", di mana dalam sebuah sistem sinergis, keseluruhan adalah lebih besar dari pada jumlah bagian-bagianya, dengan kata lain $1+1$ akan setara lebih dari 2. Makna "lebih" dalam sistem seperti ini berarti tidak akan ada batasnya.

Integrasi pelajaran TIK pada tiap pelajaran di kurikulum 2013 ini, mejadikan tiap pelajaran agar dapat memaksimalkan kemampuan siswa menggunakan teknologi komputer. Teknik Mind Mapping yang digunakan pada penelitian ini juga memanfaatkan 
teknologi komputer yaitu dengan bantuan Software IMindMap 7 yang dikembangkan langsung oleh Buzan. Pemilihan software ini didasarkan pada alasan bahwa software ini adalah satu-satunya software yang memenuhi hukum Mind Map yang sesungguhnya.

Kaitan Mind Map dengan berpikir kreatif seperti hubungan sebab akibat yang mutlak terjadi Peta pikiran dengan karakteristik yang begitu kuat pada kebermanfaatan otak secara maksimal akan menjadi alat pemikiran kreatif untuk dapat memicu ide-ide orisionil, baru, berbeda dari yang telah ada dalam menyelesaikan masalah. Hal ini sesuai hasil penelitian Arnyana (2007) menyatakan bahwa membuat Mind Map (peta pikiran) akan melatih siswa berpikir kreatif yang meliputi (1) menghasilkan sesuatu yang berbeda dari yang lain atau orisinil, (2) menghasilkan gagasan yang tidak terbatas atau menghasilkan banyak ide, (3) mampu berpikir dari yang umum ke hal-hal yang lebih detail, (4) mampu menilai karya sendiri sehingga selalu ingin memperbaikinya, dan (5) melihat permasalahan dari berbagai aspek.

Tes kemampuan berpikir kreatif pada penelitian ini lebih ditujukan pada ciri proses berpikir atau berhubungan dengan kognitif, sehingga komponen berpikir kreatif yang dimaksud yakni meliputi: Kelancaran (fluency) yakni kemampuan untuk menghasilkan kata-kata kunci yang digunakan dalam Mind Mapping dan kemampuan membuat cabangcabang yang sesuai. Keluwesan atau fleksibilitas (flexibility) yakni kemampuan menghasilkan ide-ide beragam. Kerincian atau elaborasi (elaboration) yakni kemampuan mengembangkan, membumbui, atau mengeluarkan sebuah ide. Orisinalitas (originality) yakni kemampuan untuk menghasilkan ide yang tak biasa di antara kebanyakan atau jarang.

Kolaborasi antara model pembelajaran inkuiri terbimbing dengan berbantuan teknik mencatat Mind Mapping menjadi perpaduan yang saling melengkapi satu sama lain. Inkuiri terbimbing yang direncanakan dengan banyak melibatkan hands-on and mind-on activity yang akan mengkonstruksi pemahaman konsep siswa lewat kegiatan merumuskan masalah, membuat hipotesis, merancang percobaan, melakukan percobaan, mengumpulkan dan menganalisis hasil serta menyimpulkan, akan didukung dengan teknik Mind Mapping diharapkan dapat banyak melibatkan mindson activity melalui teknik pencatatan yang dapat menjadi peta jalan pembelajaran untuk membantu mengembangkan potensi berpikir secara kreatif memfokuskan perhatian pada apa yang menjadi inti persoalan melalui asosiasi dan pengembangan imajinasi, menyelidiki setiap kemungkinan kesempatan yang terbuka dalam menyelesaikan masalah, memberikan kebebasan intelektual yang tak terbatas (Mustami:2007).
Berdasarkan uraian diatas maka tujuan penelitian ini adalah mengetahui kelayakan pengembangan perangkat pembelajaran guna meningkatkan hasil belajar dan kemampuan berpikir kreatif siswa kelas VII di SMP Al Azhar Syifa Budi, Samarinda dengan menerapkan model inkuiri terbimbing dengan teknik Mind Mapping pada materi kalor.

\section{METODE PENELITIAN}

Penelitian ini merupakan penelitian pre experiment yakni eksperimen yang dilakukan dengan memberi perlakuan tanpa adanya kelompok kontrol atau kelompok pembanding dan tanpa adanya perulangan. Kelompok eksperimen dikenai perlakuan pembelajaran dengan menggunakan model pembelajaran inkuiri terbimbing berbantuan teknik Mind Mapping kemudian diadakan pengamatan terhadap kemampuan guru dalam melaksanakan KBM sesuai RPP, aktivitas siswa, respon siswa, tes penguasaan konsep dan tes kemampuan berpikir kreatif siswa.

Rancangan penelitian menggunakan rancangan onegroup pretest-posttest design. Rancangan penelitian ini melibatkan satu kelompok yang diobservasi pada tahap pretest $\left(O_{I}\right)$ yang kemudian dilanjutkan dengan perlakuan tertentu $(X)$ dan posttest $\left(O_{2}\right)$ (Creswell, 2010). Rancangan penelitian dapat ditulis dengan bentuk:

$$
\mathrm{O}_{1} \mathrm{X} \mathrm{O}_{2}
$$

$\boldsymbol{O}_{1} \quad$ : uji awal (pretest) untuk mengetahui penguasaan siswa terhadap materi pelajaran sebelum pembelajaran.

$\boldsymbol{O}_{2}$ : uji akhir (posttest) untuk mengetahui penguasaan siswa terhadap materi pelajaran sesudah pembelajaran.

$\boldsymbol{X}$ : perlakuan pembelajaran dengan menggunakan perangkat pembelajaran model inkuiri terbimbing berbantuan teknik Mind Mapping.

Populasi dalam penelitian ini adalah siswa kelas VII di SMP Al Azhar Syifa Budi Samarinda tahun pelajaran $2013 / 2014$ yang terdiri dari 34 orang. Berdasarkan karakteristik populasi dan kecilnya peluang dilakukannya pengacakan individu, maka pengambilan sampel pada penelitian ini dilakukan dengan teknik random sampling terhadap kelas VII, kemudian didapat sampel pada penelitian ini adalah siswa kelas VII-B dengan jumlah siswa sebanyak 18 orang.

Penelitian ini merupakan penelitian pengembangan karena mengembangkan perangkat pembelajaran yang terdiri dari Rencana Pelaksanaan Pembelajaran (RPP), Buku Ajar Siswa (BAS), Lembar Kerja Siswa (LKS), dan instrument Evaluasi. Penelitian pengembangan ini mengacu pada model pengembangan Kemp, et al. (2007). Model pengembangan tersebut terdiri atas: (1) Instructional Problems, (2) Learner Characteristics, (3) 
Task Analysis, (4) Instructional Objectives, (5) Content Sequencing, (6) Instructional Strategies, (7) Instructional Delivery, (8) Evaluation Instrumens, dan (9) Instructional Resources. Perangkat pembelajaran dengan model pembelajaran Guided Inquiry dengan teknik Mind Mapping menggunakan software Buzan's IMindMap 7 yang telah dikembangkan selanjutnya diuji cobakan dalam kegiatan pembelajaran fisika di kelas VII pada pokok bahasan kalor.

Tahap pelaksanaan penerapan perangkat pembelajaran yang sudah divalidasi pada populasi yang terdiri dari 18 orang siswa. Pada tahap ini peneliti bertindak sebagai pengajar dan siswa sebagai kelompok eksperimen. Pelaksanaan penelitian dimulai dengan mengadakan tes awal (pretest), kegiatan pembelajaran yang menerapkan model inkuiri terbimbing berbantuan teknik Mind Mapping, dan uji akhir (posttest). Selama pembelajaran berlangsung dilakukan juga observasi terhadap kemampuan guru dalam mengelola KBM dan aktivitas siswa selama mengikuti kegiatan pembelajaran, serta hambatan-hambatan yang ditemui selama kegiatan pembelajaran. Selanjutnya diakhir pembelajaran siswa diberikan angket respon siswa untuk mengetahui minat siswa terhadap kegiatan pembelajaran. Penelitian pelaksanaan pembelajaran di kelas digunakan sebagai validasi empirik untuk mencari data respon, reaksi atau komentar siswa dan pengamat. Hasil penelitian ini dianalisis, kemudian digunakan untuk penyusunan laporan akhir sehingga menghasilkan naskah perangkat ajar yang siap diimplementasikan.

Penerapan perangkat pembelajaran di kelas dilaksanakan sesuai jadwal yang telah disusun oleh wakil kepala sekolah bidang kurikulum dengan alokasi waktu 8 kali pertemuan ( 8 jam tatap muka).

Instrumen yang digunakan dalam penelitian adalah alat bantu yang digunakan untuk mengumpulkan data yang diperoleh dari proses penelitian. Diantaranya adalah:

1. Lembar Validasi, digunakan untuk mendeskripsikan validitas perangkat pembelajaran yang dikembangkan.

2. Lembar Pengamatan Keterlaksanaan RPP, digunakan untuk mendeskripsikan keterlaksanaan dalam penggunaan perangkat pembelajaran yang dikembangkan sesuai urutan sitaks yang tertuang pada RPP.

3. Lembar Pengamatan Aktivitas Siswa, digunakan untuk merekam aktivitas siswa selama proses pembelajaran.

4. Lembar Pengamatan Hambatan Siswa, digunakan untuk mengamati hambatan-hambatan yang ditemui oleh guru selama proses pembelajaran.

5. Lembar Angket Respon Siswa, digunakan untuk mendapatkan informasi terhadap efektifitas, validitas, dan keterbacaan perangkat pembelajaran dan model pembelajaran yang diajarkan guru selama penelitian berlangsung.

6. Tes Penguasaan Konsep, digunakan untuk mengukur penguasaan konsep siswa sebelum dan setelah pembelajaran

7. Tes Kemampuan Berpikir Kreatif, digunakan untuk mengukur penguasaan konsep siswa sebelum dan setelah pembelajaran yang meliputi kelancaran, keluwesan, kerincian, dan orisinalitas.

Teknik yang digunakan untuk mengumpulkan data adalah melalui observasi, pemberian tes, dan pemberian angket. Analisis data dilakukan dengan menggunakan teknik deskriptif kualitatif.

\section{HASIL PENELITIAN DAN DISKUSI}

Berdasarkan hasil analisis data dapat disampaikan beberapa hal sebagai berikut:

\section{Hasil Pengembangan Perangkat Pembelajaran}

Pengembangan perangkat pembelajaran sangat diperlukan dalam rangka menunjang keterlaksanaan proses pembelajaran. Perangkat yang diterapkan dalam penelitian ini meliputi Rencana Pelaksanaan Pembelajaran (RPP), Buku Ajar Siswa, Lembar Kerja Siswa (LKS) dan Tes Penguasaan Konsep, dan Tes Kemampuan Berpikir Kreatif. Perangkat pembelajaran yang telah selesai dibuat selanjutnya dikonsultasikan dengan validator untuk menguji validitasnya. Validasi perangkat dilakukan oleh 2 orang validator dengan tujuan untuk memperoleh masukan dan catatan atas perangkat yang telah dibuat agar layak untuk diterapkan pada penelitian.

Data hasil validasi komponen RPP, Buku Ajar Siswa, LKS, Tes Penguasaan Konsep, dan Tes Kemampuan Berpikir Kreatif dianalisis secara deskriptif kualitatif, yaitu merata-rata skor yang diperoleh dari validator. Hasil analisis skor rata-rata dikategorikan pada tabel 1 sebagai berikut :

Tabel 1. Kriteria Pengkategorian Perangkat

Pembelajaran

\begin{tabular}{|l|l|l|}
\hline Interval Skor & $\begin{array}{l}\text { Kategori } \\
\text { Penilaian }\end{array}$ & Keterangan \\
\hline $3.6 \leq \mathrm{P} \leq 4$ & Sangat valid & $\begin{array}{l}\text { Dapat digunakan tanpa } \\
\text { revisi }\end{array}$ \\
\hline $2.6 \leq \mathrm{P} \leq 3.5$ & Valid & $\begin{array}{l}\text { Dapat digunakan dengan } \\
\text { sedikit revisi }\end{array}$ \\
\hline $1.6 \leq \mathrm{P} \leq 2.5$ & $\begin{array}{l}\text { Kurang } \\
\text { valid }\end{array}$ & $\begin{array}{l}\text { Dapat digunakan dengan } \\
\text { banyak revisi }\end{array}$ \\
\hline $1 \leq \mathrm{P} \leq 1.5$ & Tidak Valid & $\begin{array}{l}\text { Belum dapat digunakan } \\
\text { dan masih memerlukan } \\
\text { konsultasi }\end{array}$ \\
\hline
\end{tabular}

Format diadaptasi dari Ratumanan \& Laurens, 2011:104

Hasil penilaian perangkat oleh validator secara umum dapat dilihat pada Gambar 1. 


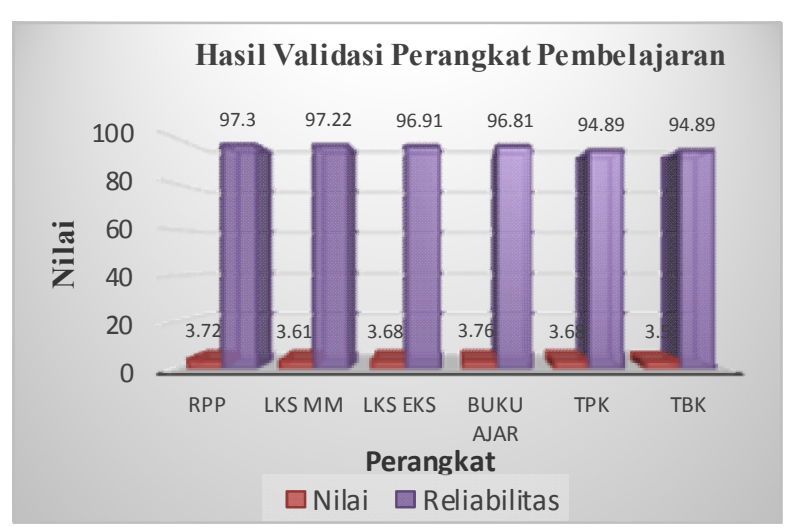

Gambar 1 Hasil Validasi dan Realibilitas Perangkat

Keterangan :

RPP : Rencana Pelaksanaan Pembelajaran

LKS MM : LKS Mind Map

LKS Eks : LKS Eksperimen

TPK : Tes Penguasaan Konsep

TBK : Tes Berpikir Kreatif

Berdasarkan Gambar 1 di atas dapat disimpulkan bahwa hasil penilaian validator terhadap perangkat yang sudah dibuat adalah sangat valid dan layak untuk digunakan dengan sedikit revisi sesuai saran validator.

\section{Tahap penerapan perangkat pembelajaran}

a. Keterlaksanaan RPP

Keterlaksanaan penggunaan perangkat pembelajaran diamati oleh dua oang pengamat. Pada penelitian ini dibuat dua siklus RPP, dimana setiap siklus RPP terdiri atas dua tahap pelaksanaan yaitu tahap pembuatan Mind Mapping dan tahap melakukan percobaan. Pemenggalan RPP menjadi dua tahapan tersebut dikarenakan keterbatasan waktu pembelajaran, sehingga tidak mencukupi jika dibuat dalam waktu satu kali pertemuan. Total pelaksanaan RPP dua tahap ini adalah empat kali tatap muka.

Hasil pengamatan terhadap keterlaksanaan pembelajaran IPA Fisika materi kalor dengan model inkuiri terbimbing berbantuan teknik Mind Mapping yang dilakukan oleh dua orang pengamat menggunakan dan disajikan secara ringkas pada tabel 3. berikut.

Tabel 3. Reliabilitas Lembar Keterlaksanaan RPP

\begin{tabular}{|c|c|c|c|}
\hline \multirow{2}{*}{$\begin{array}{c}\text { Pengamatan } \\
\text { Terhadap }\end{array}$} & \multicolumn{2}{|c|}{$\begin{array}{r}\text { Reliabilitas RPP tiap } \\
\text { tahap (\%) }\end{array}$} & \multirow{2}{*}{$\begin{array}{c}\text { Rata- } \\
\text { Rata }\end{array}$} \\
\cline { 2 - 3 } & 1 & 2 & \\
\hline Guru & 94.38 & 95.00 & 94.69 \\
\hline
\end{tabular}

Tabel 3. menunjukkan bahwa reliabilitas instrumen pembelajaran masing-masing RPP melebihi 75\%, juga dinyatakan dengan persentase keterlaksanaan dan kualitas nilai keterlaksanaan disajikan pada Gambar 2 dan Gambar 3. lembar Keterlaksanaan RPP dihitung reliabilitasnya, dengan rata-rata sebesar $94.69 \%$. Keterlaksanaan RPP

KETERLAKSANAAN RPP TAHAP 1

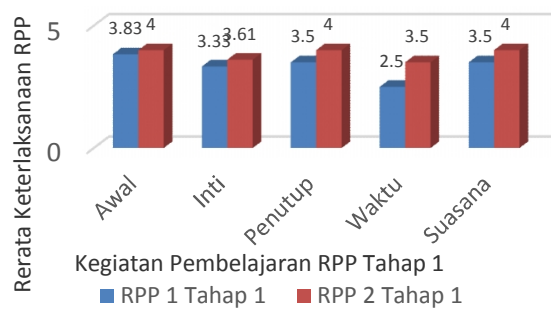

Gambar 2. Diagram keterlaksanaan RPP Tahap 1

\section{KETERLAKSANAAN RPP TAHAP 2}

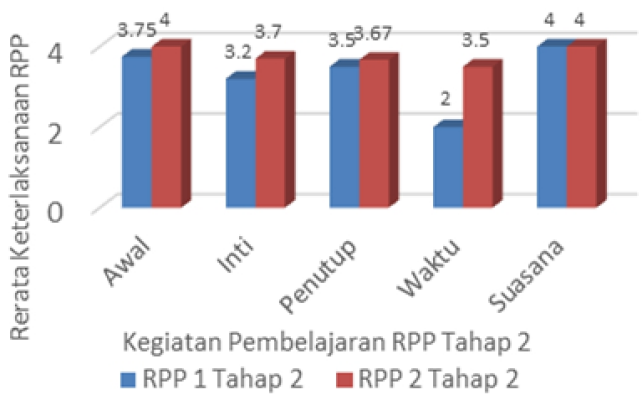

Gambar 3. Diagram keterlaksanaan RPP Tahap 2

Berdasarkan Gambar 2 dan Gambar 3 tentang keterlaksanaan RPP menunjukkan bahwa kemampuan guru dalam melaksanakan skenario pembelajaran model inkuiri terbimbing berbantuan teknik Mind Mapping dengan baik dibuktikan dengan peningkatan tiap siklus.

Peningkatan skor keterlaksanaan RPP juga terjadi karena proses belajar diupayakan semaksimal mungkin sesuai dengan Sintaks yang telah dikembangkan, dan disajikan secara ringkas pada Tabel 4 berikut

Tabel 4. Sintaks model pembelajaran inkuiri terbimbing berbantuan teknik Mind Mapping

\begin{tabular}{|l|l|}
\hline \multicolumn{1}{|c|}{ Tahap } & \multicolumn{2}{|c|}{ Kegiatan } \\
\hline $\begin{array}{l}\text { Tahap 1 } \\
\text { Menyampaika } \\
\mathrm{n} \text { tujuan dan } \\
\text { memotivasi } \\
\text { siswa }\end{array}$ & $\begin{array}{l}\text { Guru menyampaikan tujuan dan } \\
\text { memberikan motivasi berhubungan } \\
\text { dengan materi yang akan } \\
\text { disampaikan., siswa memperhatikan } \\
\text { agar termotivasi }\end{array}$ \\
\hline $\begin{array}{l}\text { Tahap 2 } \\
\text { Menyajikan } \\
\text { atau masalah }\end{array}$ & $\begin{array}{l}\text { a. Guru menyajikan fenomena, } \\
\text { untuk membimbing siswa } \\
\text { merumuskan pertanyaan. } \\
\text { bembimbing siswa hingga } \\
\text { mereka dapat menanya dalam } \\
\text { bentuk rumusan pertanyaan } \\
\text { Membuat } 3 \\
\text { Mind Map } \\
\text { a. Siswa bergabung dengan } \\
\text { kelompok Guru membimbing siswa agar } \\
\text { menemukan jawaban sementara } \\
\text { atas rumusan masalah dengan } \\
\text { mengeksplorasi pengetahuan } \\
\text { awal dari } \\
\text { menggarisbawahi buku ajar, dan }\end{array}$ \\
\hline
\end{tabular}




\begin{tabular}{|c|c|}
\hline Tahap & Kegiatan \\
\hline & $\begin{array}{l}\text { mengekstrak konsep-konsep } \\
\text { penting kemudian menuangkan } \\
\text { keywords dalam Mind Map. } \\
\text { c. Pada pertemuan pertama guru } \\
\text { memberikan bantuan berupa Clue } \\
\text { pada cabang-cabang utama } \\
\text { d. Siswa menuangkan hasil } \\
\text { eksplorasi ke dalam Mind Map } \\
\text { berbantuan software IMindMap } 7 \\
\text { Mind Map, selanjutnya bantuan } \\
\text { dikurangi. }\end{array}$ \\
\hline $\begin{array}{l}\text { Tahap } 4 \\
\text { Membuat } \\
\text { hipotesis }\end{array}$ & $\begin{array}{l}\text { Siswa diberi kesempatan untuk } \\
\text { mengajukan hipotesis dan } \\
\text { menuangkan hipotesis dalam Mind } \\
\text { Map, dengan bimbingan guru. }\end{array}$ \\
\hline $\begin{array}{l}\text { Tahap } 5 \\
\text { Merancang } \\
\text { percobaan }\end{array}$ & $\begin{array}{l}\text { Siswa merancang percobaan } \\
\text { dengan menentukan variabel- } \\
\text { variabel percobaan, dan } \\
\text { mengurutkan langkah-langkah } \\
\text { percobaan dan menuangkan dalam } \\
\text { Mind Map }\end{array}$ \\
\hline $\begin{array}{l}\text { Tahap } 6 \\
\text { Melakukan } \\
\text { percobaan }\end{array}$ & $\begin{array}{l}\text { Siswa melakukan percobaan sesuai } \\
\text { rancangan yang telah dibuat untuk } \\
\text { memperoeh data. }\end{array}$ \\
\hline $\begin{array}{l}\text { Tahap } 7 \\
\text { Mengumpulka } \\
\mathrm{n} \quad \text { dan } \\
\text { menganalisis } \\
\text { data }\end{array}$ & $\begin{array}{l}\text { a. mengumpulkan data hasil } \\
\text { percobaan. } \\
\text { b. Siswa menganalisis data } \\
\text { c. Siswa menuliskan data dan hasil } \\
\text { analisis dalam Mind Map }\end{array}$ \\
\hline $\begin{array}{l}\text { Tahap } 8 \\
\text { Pengembanga } \\
\text { n kesimpulan }\end{array}$ & $\begin{array}{l}\text { Siswa membuat kesimpulan dan } \\
\text { memasukan kesimpulan hasil } \\
\text { percobaan pada Mind Map }\end{array}$ \\
\hline $\begin{array}{l}\text { Tahap } 9 \\
\text { Menyajikan } \\
\text { hasil }\end{array}$ & $\begin{array}{l}2-3 \text { orang perwakilan dari } \\
\text { kelompok menyajikan hasil } \\
\text { percobaan dengan memanfaatkan } \\
\text { fasilitas presentation program Mind } \\
\text { Map }\end{array}$ \\
\hline
\end{tabular}

(Diadaptasi dari Joyce dan Weil, 2009)

Skor rata-rata yang tinggi dan dengan kategori baik tersebut dikarenakan semua tahap pembelajaran terlaksana dan beberapa hal lain yaitu pada kegiatan inti (1) Siswa diberi kesempatan untuk mengamati fenomena yang akan menggiring pemikiran dan ide siswa untuk merumuskan permasalahan. Proses mengamati fenomena alam, fenomena sosial, dan fenomena seni budaya, kemudian bertanya dan menalar hasil pertanyaan tersebut merupakan proses siswa untuk menjadi kreatif (Setyaningrum, 2013). (2) Masalah yang dirumuskan siswa menjadi titik awal proses penyelidikan siswa. Proses mencari jawaban sementara berupa sebuah hipotesis atas permasalahan tersebut adalah dengan cara mengeksplorasi pengetahuan awal siswa dari membaca buku ajar siswa kemudian menuangkanya dalam Mind Mapping, tujuanya agar siswa dari awal sudah aktif mengkonstruksi pengetahuan mereka sendiri. Hal ini sesuai dengan teori "pengatur kemajuan" seperti yang diungkapkan Ausuble bahwa menggarisbawahi ide-ide utama dalam suatu situasi pembelajaran yang baru merupakan bentuk pengorganisasian awal guna mengkaitkan ide-ide baru tersebut dengan pengetahuan yang telah ada pada pembelajaran (Riyanto, 2008) (3) Tahap merancang percobaan, siswa mampu menentukan variabel-variabel percobaan, menentukan alat dan bahan serta mengurutkan langkah-langkah percobaan. Semua tahapan mulai dari penyajian masalah, membuat hipotesis, menentukan variabel percobaan, menentukan alat dan bahan serta mengurutkan langkah-langkah percobaan dikerjakan dengan berbantuan software IMindMap 7. Teknik mind mapping yang diaplikasikan menggunakan software IMindMap 7 sangat praktis dan efektif dalam menuangkan ide-ide dalam mind map, terutama mengenai fleksibilitas pengubahan (editing), pengaturan ruang yang bebas, lebih mengoptimalkan kecepatan berpikir kreatif, dan lebih fleksibel serta variatif dalam presentasi (Windura, 2013). Penggunaan software IMindMap 7 juga merupakan cara yang sukses untuk mendukung eksplorasi dan presentasi ide-ide anak-anak, serta memberikan fokus yang berguna bagi siswa untuk mengatur pikiran mereka dan untuk menyajikan informasi secara jelas dan menarik (Ralston $\&$ Cook, 2007).

RPP Tahap 2 juga mendapat skor rerata yang tingi dan dalam kategori baik, hal tersebut dikarenakan beberapa hal berikut,

1) Kegiatan inti, siswa mulai melakukan percobaan. Siswa merasakan euphoria selama pembelajaran karena sangat asyik ketika melaksankan percobaan mengenai kalor. Hal ini sesuai yang dinyatakan oleh teori yang dikemukakan Piaget bahwa pendidikan yang optimal membutuhkan pengalaman yang menantang bagi pebelajar sehingga proses asimilasi dan akomodasi dapat menghasilkan pertumbuhan intelektual (Hergenhan dan Olson, 2009).

2) Tahap yang terakhir guru memberi kesempatan perwakilan kelompok menyajikan dan mengkomunikasikan hasil percobaan dan guru dapat mengomentari jalannya diskusi dan memberikan penguatan serta meluruskan yang kurang tepat. David (2006) menyatakan bahwa pembelajaran inkuiri terbimbing merupakan kegiatan melibatkan para siswa, mempromosikan restrukturisasi informasi membantu siswa mengembangkan pemahaman konsep fisika secara utuh dan terbangunnya proses sains dan sikap ilmiah. Penyajian hasil percobaan memanfaatkan media presentasi mind mapping, hal ini menambah semangat para siswa untuk mempresentasikan hasil percobaan mereka selayaknya para presenter ahli serta dapat melejitkan daya kreativitas sekaligus kemampuan berpikir kritis (Windura, 2013) 


\section{b. Aktivitas Siswa}

Aktivitas siswa selama pembelajaran diamati oleh dua orang pengamat menggunakan lembar pengamatan aktivitas siswa. Realibilitas lembar pengamatan aktivitas siswa disajikan pada Tabel 5.

Tabel 5 Reliabilitas Lembar Pengamatan Aktivitas Siswa dalam KBM

Tabel 5 menunjukkan bahwa rata-rata reliabilitas lembar pengamatan aktivitas siswa yaitu sebesar 95.98 \%. Data aktivitas siswa selama KBM disajikan dalam

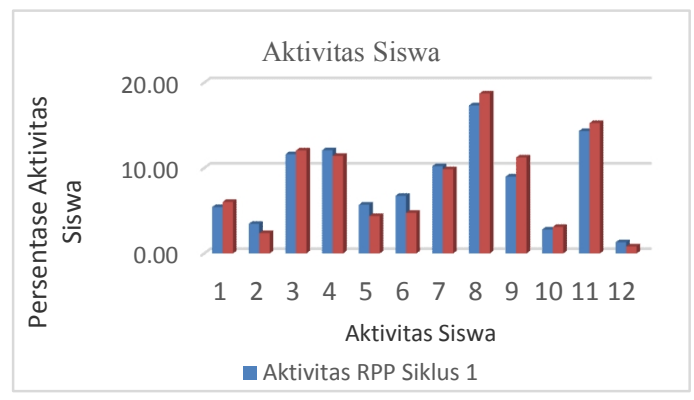

\section{Gambar 4. Persentase Aktivitas Siswa}

Hasil analisis aktivitas siswa selama pembelajaran menunjukkan bahwa model inkuiri terbimbing berbantuan teknik Mind Mapping berpusat pada siswa. Ferlina, Suyatna, dan Maharta (2012) menyatakan bahwa model pembelajaran inkuiri yang digunakan oleh guru dapat membuat siswa untuk lebih aktif dalam kegiatan pembelajaran, menanamkan dasar-dasar berfikir ilmiah pada diri siswa, sehingga dalam proses pembelajaran ini siswa lebih banyak aktif dalam memecahkan masalah. Peningkatan aktivitas siswa tiap siklus RPP menunjukkan bahwa siswa dalam kegiatan pembelajaran berada di lingkungan sosial, mereka terus menerus belajar melalui interaksi dengan orang lain di sekitar mereka. Vigotsky berpendapat bahwa perkembangan proses hidup bergantung pada interaksi sosial dan pembelajaran sosial berperan penting untuk perkembangan kognitif (Khulthau dan Todd, 2008). Peningkatan aktivitas siswa juga sesuai dengan harapan pemerintah yang terdapat dalam permendikbud nomor 81A tahun 2013 yang menegaskan bahwa prinsip pembelajaran berpusat pada siswa, mengembangkan kreativitas siswa, menciptakan kondisi belajar yang menyenangkan dan menantang serta menyediakan pengalaman belajar yang beragam melalui penerapan berbagai strategi dan metode pembelajaran yang menyenangkan, kontekstual, efektif, efisien dan bermakna. (Kemendikbud,2013).

\begin{tabular}{|c|c|c|c|}
\hline \multirow{2}{*}{$\begin{array}{c}\text { Aktivitas } \\
\text { Siswa }\end{array}$} & \multicolumn{2}{|c|}{$\begin{array}{c}\text { Reliabilitas RPP Tiap } \\
\text { Siklus (\%) }\end{array}$} & \multirow{2}{*}{$\begin{array}{c}\text { Rata-Rata } \\
\text { (\%) }\end{array}$} \\
\cline { 2 - 3 } & 1 & 2 & \\
\hline & 95.14 & 96.81 & 95.98 \\
\hline
\end{tabular}
Gambar 4

Aktivitas RPP tahap 1, ada tiga aktivitas yang persentasenya paling menonjol yaitu: 1) Membaca dan menggarisbawahi konsep-konsep penting; 2) Membuat Mind Mapping; 3) Merancang percobaan dengan bantuan Mind Mapping . Ketiga aktivitas ini merupakan bagian dari teknik mind mapping, siswa dikondisikan agar mampu mengkonstruksi sendiri pemahaman mereka melalui mengeksplorasi membaca buku ajar, kemudian mengekstrak konsep-konsep penting untuk dijadikan keyword dalam pembuatan mind mapping, setiap cabang utama akan menghasilkan anak cabang baru, dan tiap anak cabang kemungkinan juga dapat menghasilkan anak cabang yang lain sehingga dihasilkan pancaran pikiran menyeluruh yang lebih terorganisir dan lebih relevan serta dapat menghubungkan banyak ide (Al Jarf, 2009).

Pada aktivitas RPP tahap 2, ada dua aktivitas yang paling menonjol yaitu: 1) melakukan percobaan ; dan 2) menyajikan hasil lewat presentasi. Aktivitas melakukan percobaan siswa dikondisikan untuk merasa tertantang untuk menyelesaikan permasalahan yang ada di LKS Eksperimen sehingga siswa melakukan kegiatan yang ada di LKS dengan penuh motivasi. Khulthau (2010) menyatakan inkuiri terbimbing menuntut siswa untuk mengembangkan langkah kerja dalam memecahkan masalah yang telah diberikan oleh guru melalui LKS jenis challenge activity, inkuiri terbimbing masih memegang peranan guru dalam memilih topik/bahasan, pertanyaan dan menyediakan materi, akan tetapi siswa diharuskan untuk melakukan penyelidikan, menganalisis, dan sampai kepada kesimpulan.

c. Tes Penguasaan Konsep Siswa

Tes Penguasaan Konsep diberikan dua kali tes yaitu sebelum pembelajaran (pretest) dan setelah pembelajaran (posttest) dengan model pembelajaran inkuiri terbimbing berbantuan teknik mind mapping. Hasil dari tes penguasaan konsep siswa digunakan untuk menentukan ketuntasan hasil belajar aspek pengetahuan siswa. Hasil ketuntasan belajar siswa disajikan dalam Tabel 6 berikut:

Tabel 6. Hasil Ketuntasan Belajar Siswa

\begin{tabular}{l|l|l|l|l|l|}
\hline & & Nama \\
Siswa & $\begin{array}{l}\text { Nilai } \\
\text { gain }\end{array}$ & Kategori & $\begin{array}{l}\text { Nilai } \\
\text { Post } \\
\text { test }\end{array}$ & $\begin{array}{l}\text { Predik } \\
\text { at }\end{array}$ & $\begin{array}{l}\text { Ketuntasan } \\
\text { Individu }\end{array}$ \\
\hline B1 & 0.80 & Tinggi & 3.33 & B + & Tuntas \\
\hline B2 & 0.68 & Sedang & 3 & B & Tuntas \\
\hline B3 & 1.00 & Tinggi & 4 & A & Tuntas \\
\hline B4 & 0.75 & Tinggi & 3 & B & Tuntas \\
\hline B5 & 0.87 & Tinggi & 3.33 & B+ & Tuntas \\
\hline B6 & 0.75 & Tinggi & 3 & B & Tuntas \\
\hline B7 & 0.76 & Tinggi & 3.33 & B + & Tuntas \\
\hline B8 & 0.85 & Tinggi & 3.66 & A- & Tuntas \\
\hline B9 & 0.89 & Tinggi & 4 & A & Tuntas \\
\hline B10 & 0.78 & Tinggi & 3 & B & Tuntas \\
\hline
\end{tabular}




\begin{tabular}{l|l|l|l|l|l|}
\hline \hline $\begin{array}{l}\text { Nama } \\
\text { Siswa }\end{array}$ & $\begin{array}{l}\text { Nilai } \\
\text { gain }\end{array}$ & Kategori & $\begin{array}{l}\text { Nilai } \\
\text { Post } \\
\text { test }\end{array}$ & $\begin{array}{l}\text { Predik } \\
\text { at }\end{array}$ & $\begin{array}{l}\text { Ketuntasan } \\
\text { Individu }\end{array}$ \\
\hline B11 & 0.79 & Tinggi & 3.33 & B + & Tuntas \\
\hline B12 & 0.95 & Tinggi & 4 & A & Tuntas \\
\hline B13 & 0.84 & Tinggi & 3.66 & A- & Tuntas \\
\hline B14 & 0.79 & Tinggi & 3.33 & B + & Tuntas \\
\hline B15 & 0.88 & Tinggi & 3.66 & A- & Tuntas \\
\hline B16 & 0.76 & Tinggi & 3 & B & Tuntas \\
\hline B17 & 0.77 & Tinggi & 3 & B & Tuntas \\
\hline B18 & 0.89 & Tinggi & 3.66 & A- & Tuntas \\
\hline $\begin{array}{l}\text { Rat } \\
\text { a- } \\
\text { rata }\end{array}$ & $\mathbf{0 . 8 2}$ & Tinggi & $\mathbf{3 . 4 0}$ & $\mathbf{A}^{-}$ & Tuntas \\
\hline
\end{tabular}

berpikir kreatif bila skor rata-rata minimal pada persentase $61,2 \%$. Kriteria kemampuan berpikir kreatif secara rinci dapat dilihat pada tabel 9

Tabel 7. Kriteria Penilaian Kreativitas Berpikir

\begin{tabular}{|c|c|}
\hline $\begin{array}{c}\text { Rentang Skor } \\
\text { Rata-Rata }\end{array}$ & Kategori \\
\hline $81,6 \%-100 \%$ & Sangat Kreatif \\
\hline $61,2 \%-81,5 \%$ & Kreatif \\
\hline $40,8 \%-61,1 \%$ & Cukup Kreatif \\
\hline $20,4 \%-40,7 \%$ & Kurang Kreatif \\
\hline $0,0 \%-20,3 \%$ & Tidak Kreatif \\
\hline
\end{tabular}

(Adaptasi dari Khanafiyah, S \& Rusilowati, A. 2010)

Hasil penilaian kemampuan berpikir kreatif siswa disajikan dalam Tabel 8

Tabel 8 Analisis $N$-Gain Score Berpikir Kreatif

Berdasarkan Tabel 6, Penerapan hasil pengembangan perangkat dapat meningkatkan ketuntasan hasil belajar siswa, dibuktikan dengan $\mathrm{N}$ gain rata-rata dari kelas VII adalah 0.82 dengan kategori tinggi (Hake, 1999). Hal ini sesuai dengan teori penemuan yang dikemukakan oleh Bruner, bahwa untuk meningkatkan prestasi belajar (dalam hal ini yang dimaksud adalah penguasaan konsep) maka siswa harus tahu bagaimana mentransformasi pengetahuan secara aktif. Seperti pada pembelajaran dengan model inkuiri terbimbing berbantuan teknik Mind Mapping, siswa diajarkan untuk mentransformsi pengetahuan dengan jalan penyelidikan serta dibantu media Mind Map yang mempermudah mengorganisasikan konsep yang telah diperoleh, sehingga informasi tersebut dapat bertahan lama dalam pikiran siswa.

Hasil peningkatan penguasaan konsep di atas diperkuat dengan Wenning (2011) bahwa pembelajaran melalui inkuiri membuat siswa belajar sains dengan pemahaman yang sangat baik, dan hasil penelitian Maliyah (2012), Astuti (2013), dan David (2006) yang menyatakan bahwa pembelajaran dengan menggunakan proses pembelajaran inkuri terbimbing dapat meningkatkan kognitif siswa serta El-Mona \& ElKhalick (2008) menemukan bahwa peserta dalam kelompok Mind Mapping mencapai hasil yang signifikan secara statistik pada semua kategori sasaran (pemahaman konseptual dan penalaran praktis) dan tingkat prestasi (dasar, cakap, dan mahir).

\section{d. Tes Kemampuan Berpikir Kreatif}

Lembar penilaian kemampuan berpikir kreatif dalam penelitian ini dikembangkan sendiri oleh peneliti dengan mengacu pada empat ukuran penilaian kreatif yang digagas oleh Torrance (1975) dalam Torrance Test of Creative Thinking (TTCT) dan penilaian kreatif produk yang digagas oleh Guilford (1967) dalam Structure of Intelect Test, yaitu fluency (kelancaran), flexibility (keluwesan), originality (keaslian), dan elaboration (elaborasi). Siswa dikatakan mampu

\begin{tabular}{|c|c|c|c|c|c|c|c|}
\hline \multirow[b]{2}{*}{ No } & \multirow[b]{2}{*}{$\mathbf{S}$} & \multicolumn{2}{|c|}{ PRETEST } & \multicolumn{2}{|c|}{ POSTTEST } & \multirow[b]{2}{*}{$\begin{array}{l}\mathrm{N}- \\
\text { Gain }\end{array}$} & \multirow[b]{2}{*}{ KT } \\
\hline & & $\begin{array}{l}\text { Skor } \\
\text { (\%) }\end{array}$ & KR & $\begin{array}{l}\text { Skor } \\
\text { (\%) }\end{array}$ & KR & & \\
\hline 1 & B & 40.6 & KK & 84.3 & SK & 0.78 & Tinggi \\
\hline 2 & B & 31.2 & KK & 65.6 & $\mathrm{~K}$ & 0.52 & Sedang \\
\hline 3 & $\mathrm{~B}$ & 34.3 & KK & 84.3 & SK & 0.80 & Tinggi \\
\hline 4 & B & 21.8 & KK & 59.3 & CK & 0.50 & Sedang \\
\hline 5 & B & 28.1 & KK & 56.2 & CK & 0.41 & Sedang \\
\hline 6 & B & 34.3 & KK & 96.8 & SK & 1.00 & Sedang \\
\hline 7 & B & 31.2 & KK & 68.7 & $\mathrm{~K}$ & 0.57 & Sedang \\
\hline 8 & B & 34.3 & KK & 84.3 & SK & 0.80 & Tinggi \\
\hline 9 & B & 53.1 & CK & 78.1 & $\mathrm{~K}$ & 0.57 & Sedang \\
\hline 10 & B & 34.3 & KK & 93.7 & SK & 0.95 & Tinggi \\
\hline 11 & B & 28.1 & KK & 81.2 & $\mathrm{~K}$ & 0.77 & Tinggi \\
\hline 12 & B & 28.1 & KK & 93.7 & SK & 0.95 & Tinggi \\
\hline 13 & B & 43.7 & CK & 87.5 & SK & 0.82 & Tinggi \\
\hline 14 & B & 40.6 & KK & 71.8 & $\mathrm{~K}$ & 0.56 & Sedang \\
\hline 15 & B & 50 & CK & 93.7 & SK & 0.93 & Tinggi \\
\hline 16 & B & 43.7 & CK & 93.7 & SK & 0.94 & Tinggi \\
\hline 17 & B & 50 & CK & 96.8 & SK & 1.00 & Tinggi \\
\hline 18 & B & 28.1 & KK & 78.1 & $\mathrm{~K}$ & 0.73 & Tinggi \\
\hline \multicolumn{2}{|c|}{ Jumlah } & $\begin{array}{l}256 . \\
25\end{array}$ & & $\begin{array}{l}600 . \\
00\end{array}$ & & & \\
\hline \multicolumn{2}{|c|}{ Rerata } & 32.03 & KK & 75.00 & $\mathbf{K}$ & 0.76 & Tinggi \\
\hline \multicolumn{2}{|c|}{$\begin{array}{l}\text { Skor } \\
\text { Maks }\end{array}$} & \multicolumn{4}{|c|}{87.50} & & \\
\hline \multicolumn{2}{|c|}{$\begin{array}{l}\text { Skor } \\
\text { Min }\end{array}$} & \multicolumn{4}{|c|}{25.00} & & \\
\hline
\end{tabular}

Keterangan:

$\begin{array}{ll}\text { S : Siswa KR: Kriteria } & \text { KT : Kategori } \\ \text { KK : Kurang Kreatif } & \text { CK : Cukup Kreatif } \\ \text { K : Kreatif } & \text { SK : Sangat Kreatif }\end{array}$

Tabel 8 menunjukan bahwa terjadi peningkatan skor siswa dari pretest ke posttest, sekaligus peningkatan kemampuan berpikir kreatif seluruh siswa secara individual. Secara klasikal, kemampuan berpikir kreatif siswa mengalami peningkatan dari skor rata-rata $32.03 \%$ (tidak kreatif) menjadi $75.00 \%$ (kreatif). NGain rata-rata setelah pelaksanaan model inkuiri terbimbing berbantuan teknik mind mapping sebesar 0.76 dengan kategori tinggi (Hake, 1999). 
Skor kemampuan berpikir kreatif siswa yang tinggi dan dalam kategori kreatif setelah pembelajaran dengan model inkuiri terbimbing berbantuan teknik mind mapping dikarenakan semua aspek berpikir kreatif dapat ditingkatkan oleh siswa yang meliputi : (1) Aspek Kelancaran, indikatornya adalah kemampuan siswa memunculkan banyak gagasan dalam membuat mind map dan tercermin dalam kelengkapan ide-ide yang dituangkan dalam mind map serta sikap konsisten siswa dalam penempatan satu kata kunci dalam satu cabang. Kelengkapan ide-ide yang tertuang dalam satu mind map, menjadi bukti bahwa bahwa mind map menghasilkan gambaran keseluruhan dari konsep yang mereka pelajari, dengan lebih efisien karena tidak memerlukan ruang yang terlalu banyak (Buzan, 2006). Aspek kelancaran juga berkaitan dengan seberapa cepat siswa mampu mengorganisir ide-ide penting agar menjadi konsep yang utuh. Penggunaan digital mind mapping dengan software IMind Map 7 membuat kegiatan membuat mind map jauh lebih cepat dan fleksibel terutama dalam hal pengubahan (editing), penyimpanan dan presentasi. Hal ini senada dengan penelitian Al-Jarf, R. (2009) yang menyatakan bahwa Software Mind Map mendorong pemikiran kreatif dan mereka menjadi lebih cepat dalam menghasilkan dan mengorganisir ide-ide untuk menulis mereka.

(2) Aspek Keluwesan (flexibility), terdapat dua hal yang diukur dalam aspek keluwesan membuat mind mapping ini yang pertama adalah mind mapping produk yang dihasilkan siswa mampu mencermikan ide-ide dari hal yang umum ke hal-hal yang lebih detail dan yang kedua yaitu Asosiasi (koneksi) antar ide-ide. Berpikir dari hal yang umum ke hal yang detil, menstimulus siswa untuk lebih rajin membaca berulang sumber bacaan yang akan dibuat peta pikiran, siswa akan tertantang untuk terus menuangkan pancaran pemikiran yang lebih spesifik (Buzan, 2006). Indikator Asosiasi (koneksi) antar ide-ide diukur dari banyaknya siswa memberikan garis penghubung (conector line) antar cabang satu dengan yang lainya. Berdasarkan hasil pengamatan tes kemampuan berpikir kreatif, belum banyak siswa yang memberikan garis penghubung pada mind map mereka, hal itu kemungkinan disebabkan tingkat perkembangan kognitif mereka masih dalam tingkat operasional konkret, belum mampu mengaitkan ide-ide yang sifatnya abstrak. (3) Aspek keterampilan merinci (elaboration), indikatornya siswa mampu memperinci detil-detil dari suatu gagasan sehingga lebih menarik. (4) Aspek Berpikir orisinil (Originality), merupakan kemampuan untuk menghasilkan ide-ide unik, tidak biasa, "eksentrik" (Buzan,2006). Indikator yang diukur dari aspek orisinil meliputi dua hal yaitu menambahkan gambar-gambar (images) unik dan berbeda dan kemiringan cabang maksimal $45^{\circ}$ dan membuat kombinasi warna dan bentuk yang unik dan tidak lazim. Gambar atau "images" atau "icon" digunakan untuk menunjang ide-ide penting atau menggantikan kata kunci dalam mind map. Informasi dalam Otak manusia akan lebih mudah diserap atau dipanggil kembali, jika informasi yang masuk berupa gambar, simbol, suara, dan bukan dalam bentuk huruf dan tulisan yang linier (Buzan, 2006). Keunikan yang dihasilkan dengan banyaknya warna, gambar atau ikon akan membantu daya ingat siswa (Buzan, 2006).

\section{e. Respon Siswa}

Berdasarkan hasil analisis respon siswa terhadap pengembangan perangkat pembelajaran dan pelaksanaan pembelajaran dengan model inkuiri terbimbing berbantuan teknik mind mapping didapatkan hasil bahwa sebanyak $80.92 \%$ siswa merespon dengan kriteria kuat (Riduwan, 2010). Siswa merespon positif. Hasil respon siswa secara ringkas dapat disimpulkan sebagai berikut

1. LKS dan Buku Ajar yang dikembangkan menarik dan mudah dipahami untuk meningkatkan penguasaan konsep dan kemampuan berpikir kreatif.

2. Tes Penguasaan Konsep dan Tes Kemampuan Berpikir Kreatif yang dikembangkan mudah dipahami dalam hal petunjuk pengerjaan, bahasa dan gambar penunjang.

3. Guru telah memberi bimbingan di luar waktu pembelajaran mengenai sintaks keterampilan proses sains dan cara menggunakan Software IMind Map 7.

4. Setelah kegiatan inkuiri siswa lebih mudah dalam merumuskan masalah, menentukan hipotesis, merancang percobaan, melakukan percobaan, menganalisis serta menyimpulkan hasil penyelidikan.

5. Teknik Mind Mapping membantu dalam mengeksplorasi pengetahuan awal siswa, memudahkan dalam merancang percobaan, memudahkan siswa untuk memetakan pengetahuan siswa secara keseluruhan dan membuat siswa lebih mandiri dalam perolehan pengetahuan.

6. Model inkuiri terbimbing berbantuan teknik Mind Mapping memudahkan siswa dalam menguasai konsep dan meningkatkan kemampuan berpikir kreatif siswa.

Respon siswa yang positif ini sesuai dengan hasil penelitian dari Maliyah, dkk. (2012) yang menyatakan bahwa dengan menerapkan model Guided Inquiry (inkuiri terbimbing) mendapat respon yang sangat baik dalam meningkatkan motivasi belajar siswa.

\section{f. Hambatan}

Pelaksanaan pembelajaran fisika dengan perangkat pembelajaran fisika model inkuiri terbimbing 
ditemukan beberapa hambatan yang dapat dilihat pada Lampiran 2p dan Tabel 9 di bawah ini.

Tabel 9. Kendala-kendala selama proses pembelajaran pada uji coba II

\begin{tabular}{|c|c|c|}
\hline No. & Jenis Kendala & Solusi Alternatif \\
\hline 1. & $\begin{array}{lr}\text { Waktu pembelajaran } \\
\text { kurang karena siswa } \\
\text { datang telat dari } \\
\text { perpindahan } \\
\text { pelajaran. }\end{array}$ & $\begin{array}{l}\text { Menyuruh siswa agar } \\
\text { tidak terlambat ketika } \\
\text { pergantian jam. }\end{array}$ \\
\hline 2. & $\begin{array}{l}\text { Siswa belum terbiasa } \\
\text { mengikuti } \\
\text { pembelajaran dengan } \\
\text { model inkuiri } \\
\text { terbimbing yang } \\
\text { menggunakan } \\
\text { keterampilan proses. }\end{array}$ & $\begin{array}{lr}\text { Memberikan } & \\
\text { pengarahan } & \text { dan } \\
\text { informasi } & \text { kepada } \\
\text { siswa } & \text { tentang } \\
\text { pembelajaran } & \text { dengan } \\
\text { model } & \text { inkuiri } \\
\text { terbimbing } & \text { dengan } \\
\text { harapan siswa lebih } \\
\text { mudah } & \text { dalam } \\
\text { mengikuti } & \\
\text { pembelajaran. } & \end{array}$ \\
\hline 3. & $\begin{array}{lr}\text { Siswa belum } \\
\text { menyelesaikan mind } \\
\text { map rancangan } \\
\text { percobaan yang } \\
\text { meliputi rumusan } \\
\text { masalah, hipotesis, } \\
\text { variabel sebelum } \\
\text { melaksanakan } \\
\text { percobaan, sehingga } \\
\text { waktur untuk } \\
\text { melaksanakan } \\
\text { percobaan } \\
\text { terkurangi. }\end{array}$ & $\begin{array}{l}\text { Menyuruh siswa agar } \\
\text { menyelesaikan mind } \\
\text { map rancangan } \\
\text { percobaan di rumah } \\
\text { secara berkelompok. }\end{array}$ \\
\hline 4. & $\begin{array}{lr}\text { Siswa } & \text { kesulitan } \\
\text { dalam menambahkan } \\
\text { gambar-gambar yang } \\
\text { menunjang } & \text { ide-ide } \\
\text { dalam } & \text { cabang- } \\
\text { cabang } & \text { mind } \\
\text { mapping } & \end{array}$ & $\begin{array}{l}\text { Memberikan } \\
\text { pengarahan pada siswa } \\
\text { agar memanfaatkan } \\
\text { menu "images" dan } \\
\text { "icon" dalam IMind } \\
\text { Map } 7 \text { serta dapat } \\
\text { mendownload } \\
\text { gambar-gambar dari } \\
\text { internet. }\end{array}$ \\
\hline
\end{tabular}

\section{KESIMPULAN}

\section{A. Simpulan}

Dari berbagai uraian, pendapat dan hasil penelitian yang relevan maka perangkat dengan model inkuiri terbimbing berbantuan teknik Mind Mapping dalam materi Kalor yang dikembangkan sudah valid, praktis, dan efektif (layak digunakan) untuk meningkatkan penguasaan konsep dan kemampuan berpikir kreatif siswa SMP

\section{B. Saran}

$\mathrm{m}$ Berdasarkan pada hasil penelitian yang telah dilakukan, disarankan bahwa dalam menerapkan model pembelajaran inkuiri terbimbing berbantuan teknik Mind Mapping supaya memperhatikan:

1. Penerapan rencana pelaksanaan pembelajaran sudah baik namun guru harus lebih bisa mengelola waktu selama pembelajaran agar pembelajaran bisa berjalan lebih efektif dan efisien.

2. Peneliti lain perlu melatih siswa untuk lebih mengembangkan kemampuan penggunaan keterampilan proses dan keterampilan membuat mind map dalam pembelajaran untuk melakukan kegiatan penyelidikan. Pengenalan awal bisa dilakukan pada waktu khusus, agar saat proses pembelajaran siswa tidak kesulitan menyelesaikan LKS dan melakukan penyelidikan.

3. Penggunaan aplikasi IMindMap 7 dapat menjadi rekomendasi, untuk digunakan pada materi fisika yang lain atau pada mata pelajaran lain, karena sangat membantu mengorganisasikan pengetahuan yang telah diperoleh siswa selama dan setelah pembelajaran.

4. Pengembangan perangkat pembelajaran model inkuiri terbimbing dapat meningkatkan kemampuan berpikir kreatif siswa SMP pada materi kalor sehingga diharapkan untuk penelitian lanjutan pada materi fisika yang lain dan dilengkapi dengan media pembelajaran yang lebih memudahkan siswa memvisualkan konsep-konsep yang abstrak.

\section{REFERENSI}

Al-Jarf, R. (2009). "Enhancing freshman students writing skills with a mind mapping software". Paper presented at the 5th International Scientific Conference, eLearning and Software for Education, Bucharest.

Arnyana. (2007). "Pengembangan peta pikiran untuk peningkatan kecakapan berpikir kreatif siswa". Jurnal pendidikan dan pengajaran UNDIKSHA.

Buzan, Tony. (2006). Buku pintar mind map. Jakarta : PT. Gramedia Pustaka Utama.

David, M. H. (2006). Instructor's guide to processoriented guided-inquiry learning. SUNY: Stony Brook University.

El-Mona, A, I. and El-Khalick, Abd. F. (2008). The influence of mind mapping on eighth grader's science achievement. School Science and Mathematics

Ferlina, Intan., Suyatna, \& Maharta. (2012). "Perbandingan hasil belajar fisika siswa antara pembelajaran menggunakan model kooperatif tipe grup investigasi dengan inkuiri terbimbing". Jurnal Pendidikan Fisika, Nomor 2. Volume 1. Halaman 175.

Forum Mangunwijaya VII. (2013). Menyambut kurikulum 2013. Jakarta : PT. Kompas Media Nusantara.

Gie, T.L (2003). Melejit dengan kreatif. Jakarta: Gema Insani. 
Hake. (1999). Analyzing change/gain scores. (Online). Tersedia http://www. physicsindiana.edu/sdi/Analyzing-ChangeGain. pdf.

Hergenhahn, B.R. dan Olson, M.H,. (2009). Theories of learning (teori belajar) edisi bahasa Indonesia. Jakarta: Kencana Prenada Media Group.

Kementerian Pendidikan dan Kebudayaan. (2013). Modul pelatihan implementaasi Kurikulum 2013. Jakarta: Badan Pengembangan Sumber Daya Manusia Pendidikan dan Kebudayaan dan Penjaminan Mutu Pendidikan.

Kemp, J. E. (2007). Designing effective instruction. New York: Macmillan College Publishing Company.

Khanafiyah, S \& Rusilowati, A. (2010). Penerapan pendekatan modified free inquiry sebagai upaya meningkatkan kreativitas mahasiswa calon guru dalam mengembangkan jenis eksperimen dan pemahaman terhadap materi fisika. (Tesis magister pendidikan tidak dipublikasikan). Universitas Negeri Semarang

Kuhlthau, C Carol. (2010). Guided inquiry" school libraries worldwide. Vol 16 No. 1 January 2010. Pp. 17-28.

Maliyah, N. (2012) . "Pembelajaran fisika dengan inkuiri terbimbing melalui metode eksperimen dan demontrasi diskusi ditinjau dari kemampuan matematik dan kemampuan verbal siswa”. Jurnal Inkuiri. Vol. 1, No. 3, PP. 227234.

Mustami, M.K. (2007). Pengaruh model pembelajaran synectics yang dipandu mind maps dan kooperatif STAD terhadap kemampuan berpikir kreatif, sikap kreatif dan penguasaan materi biologi siswa smp kota Makassar. (Disertasi Doktor tidak dipublikasikan). Universitas Negeri Malang.

Ralston, J. and Cook, D. (2007). "Collaboration, ICT and Mind Mapping". Reflecting Education, Vol. 3, No. 1, pp 61-73.

Ratumanan, G.T., dan T, Laurens. (2006). Evaluasi hasil yang relevan dengan memecahkan problematika belajar dan mengajar. Bandung:CV Alfabeta.

Riyanto, Yatim. (2008), Paradigma Baru Pembelajaran, Penerbit Kencana Prenada Media Group, Jakarta.

Wenning C, J. (2011).. (2010). "Using inquiry spectrum learning to teach science". Journal of Pysics Teacher Education. Vol. 5 No. 3 Summer. pp. 11-17.

Windura, Sutanto. (2010). Mind Map langkah demi langkah. Jakarta: Eex Media Komputindo. . (2013). $1^{\text {st }}$ MIND MAP untuk siswa, guru \& orang tua. Jakarta : PT. Elex Media Komputindo. 